\title{
The Research of the Generalized Project Management and The Generalized Project Management Maturity
}

\author{
Zhenzhi Yao \\ China Center for Information Industry Development, Beijing, China \\ yaozz@ccidgroup.com
}

Keywords: Project management Project management maturity

\begin{abstract}
Based on the concept of project management, the traditional management object, the main work and deficiencies, we give the definition and significance of generalized project management. Combined with the traditional project management maturity definition and classification of project management maturity, we determine the definition of the generalized project management maturity and the level, build the evaluation index system, and expound the general project management maturity common calculation method.
\end{abstract}

\section{Introduction}

With the development of economy in China, the environment is becoming more and more complicated and the project management is becoming more and more important. Management which included project approval、 execution and acceptance, change relates to many elements of composite system, such as laboratory construction, quality maintenance, academic exchanges, cultivation of experts, association participation and so on. Mature project management is essential for the optimization of enterprise resources and the sustainable development of enterprises. In a sense, the project management maturity decides the success or failure of enterprise development.

\section{Concept and classification of project management}

Project management concept. Project management as an important branch of the management science, is a multi elements compound system including the promotion and application; is the whole process of rules of conduct, which the enterprise guarantee project quality, enlarge brand influence, promote the business transformation and upgrading, enhance the competitive vitality; is the practical operation of the process including pre project feasibility study, planning and design, mid project implementation and control, and late in the project evaluation; is the means which collaborative research and development, and effective the sustainable development of enterprises. The project management can be divided into the traditional project management and general project management.

Traditional project management. The traditional project management is the process from the application, project approval, implementation, acceptance, assessment to the filing process. Its purpose is to complete the project setting target through the institutionalization and scientific management. The main management includes the organization way, the project schedule, the project cost budget and the project quality and the logistics support, etc. [1].

The traditional project management is mainly focused on the object of project management, and the target of the project is to achieve. Only in a certain extent, this kind of management style cannot be given the effectiveness of projects, links between separate projects, ignore the research outcomes and benefits of different projects of the resonance effect of the enterprise's own. This management mode is suitable for small scale, technology weak, labor intensive enterprise, but it has a lot of disadvantages for large-scale enterprises, heavy research and development, and intelligence type: 
One is that the limitations of the management of the project results difficult to expand in depth. Due to the managers to focus on project indicators of the completion and implementation of the process specification, it will cause the project involves technology and produce results understand outwardly, the impact of the enterprise to bring the consequences of the incomplete.

Two is equipped with uneven lead to work efficiency frustrated. In traditional project management, the researchers often does not account for the dominant position. For the enterprises of the drawbacks of the small scale, weak technology, labor intensive is not obvious. But the lack of personnel or in a weak, will reduce the efficiency in the implementation of all aspects of the project application, approval, implementation, inspection, evaluation and impact.

Three is the isolated project caused the collaborative innovation weak. In traditional project management, the projects is not associated each other. The project's results can be used smooth. The phenomenon of island project is very serious. It is difficult to Cooperative development between projects and project results. Eventually, it led to the lack of enterprise innovation.

Generalized project management. According to the foregoing analysis, we know that the traditional project management has some disadvantages to the group, paying attention to research and development, intelligence large enterprises. This will need to change the traditional management mode to the generalized project management, in order to enhance the enterprise's competitive energy and development of power.

The generalized project management on the basis of the traditional project management, make the laboratory construction, maintenance of certification, academic exchanges, nurture experts $t$ as the part of itself. It change the original simple project management into "project + " - collaborative innovation and the development of integrated management system. Generalized project management is of great significance for large-scale enterprises, heavy research and development and intelligence. First, the generalized project management makes the laboratory construction project management as a part the management category. It can be used the different results, refining the generic technology laboratory construction, enhance the power of enterprise development; secondly, the general project management making the qualification maintenance management as the object, can enrich the project management means, accord to their own business needs to apply the corresponding qualification and improve the market competition of the enterprise; thirdly, the general project management making the academic exchanges and expert management as the content, through internal and external academic exchanges, expand the influence and voice of the enterprise; finally, the general project management enhance the enterprise the ability of innovative services through the research by interaction.

\section{Project management maturity}

Project management maturity definition. The project management maturity is the overall capability of the organization to achieve the strategic objectives. The project management maturity model is a method and tool to help the project management organizations to evaluate and improve their project management level [2]. As the enterprise project management capability's metrics, the project management maturity can be used to measure the tissue's ability. It is a set of scientific system and method, used to characterize the organization project management's process from junior to senior development [3].

Project management maturity level. The software industry widely used "Capability Maturity Model" that enterprise need to go through initial level, repeatable level, defined level, management level and optimization level, etc., eventually reach maturity [4]. Drawing on software capability maturity model classification, the project management maturity is divided into disorder level, basic level, standard level, platform level, optimization level. Disorder level refers to the enterprise project management is in a chaotic state, do not set up corresponding project management department and specific project management personnel arrangements, has not the rules and regulations of the project 
management; basic level is refers to the enterprise to set up the corresponding project management department, arrange the part-time or full-time project managers and introduced some of the necessary project management rules and regulations; Standard grade is refers to the enterprise according to their own needs, establish the specialized departments and professional project management, perfect the corresponding management system, project management standards, norms enterprises to be supported and implemented; platform level is refers to the enterprise project management system, standard and specification be promoted in enterprise interior all departments, and build a platform to improve the implementation and efficiency; The optimization level is that the enterprise can plan all the internal control system from the strategic management height, and the project management is in the process of continuous improvement and continuous optimization [5].

\section{Generalized project management maturity}

Generalized project management maturity definition. The generalized project management maturity is the overall capability of the organization to achieve the strategic objectives on the management of "project +". Here "project +" not only refers to the project, also includes for carrying out the project management activities involved the laboratory construction, maintenance of certification, academic exchanges, cultivation of experts, association participation factor an so on. The generalized project management maturity model is a method and tool used to help organizations evaluate and improve their own "project +" management level. As a metric of the "project +" management ability of enterprise, the generalized project management maturity can be used to measure the tissue project implementation and coordination ability of innovation and development, can be used to reflect the organizational competitive vitality and momentum.

Generalized project management maturity level. Be similar with the project management maturity degree which divided the disorder level, basic level, standard level, platform level, optimization level, the general project management maturity according to the actual situation of enterprise management and ability, divided into five levels: the project level, feature level, fusion level, platform level and collaboration level. Project level refers to enterprises still remain in the traditional project management maturity stage, and the contents of the laboratory construction, maintenance of certification, academic exchanges, breeders, association participation are not separated departments or personnel managed. Feature level based on the traditional project management maturity, makes the laboratory construction and maintenance of certification, academic exchanges, breeders, association participation management as the daily management system, and established a full-time departments or personnel responsibility. But these factors have no association between each other. Fusion level refers to the factors gradual integration, in order to play the role of project results, to expand the influence of the enterprise, raise the academic level, and develop rules and regulations to security the factors integration and development. Platform level refers to between the various elements of the general project management in conjunction with each other, in order to promote the effect, and realizes the management platform system and service sharing. Collaboration level refers to the various elements of the results be maximized the effectiveness, and on the basis of innovation of business model, technology and other aspects of development, becomes the source of enterprise competitive vitality and momentum.

Generalized project management maturity index evaluation system. According to the general project management covers the project to control, laboratory construction, maintenance of certification, academic exchanges, cultivation of experts, association participation and so on, and combined with the author's own work experience and the actual situation, we construct generalized project maturity index evaluation system, as follows: 
Generalized project management maturity index evaluation system

\begin{tabular}{|c|c|}
\hline Primary indicator & Grade two index \\
\hline \multirow{4}{*}{ Project to control } & Project planning and reporting \\
\hline & Project execution and supervision \\
\hline & Post project evaluation \\
\hline & Project result marketing \\
\hline \multirow{8}{*}{ Laboratory construction } & National special project \\
\hline & Common technology \\
\hline & Classification and localization \\
\hline & Experts and team \\
\hline & Market efficiency \\
\hline & Research findings \\
\hline & Operation and management \\
\hline & Foreign cooperation and exchange \\
\hline \multirow{4}{*}{$\begin{array}{l}\text { Maintenance of } \\
\text { certification }\end{array}$} & Routine maintenance \\
\hline & Qualifications and business areas \\
\hline & Qualification expansion \\
\hline & Qualification upgrade \\
\hline \multirow{5}{*}{ Academic exchanges } & Training regularly \\
\hline & Academic lectures and reports \\
\hline & Foreign academic exchange \\
\hline & Academic research results \\
\hline & Academic conference and activity organization \\
\hline \multirow{4}{*}{ Cultivation of experts } & Business expert \\
\hline & Key business experts \\
\hline & Expert interaction and exchange \\
\hline & External experts \\
\hline \multirow{4}{*}{$\begin{array}{l}\text { Association } \\
\text { participation }\end{array}$} & Association and unit key business \\
\hline & Association exchange and cooperation \\
\hline & Participation of the association activities \\
\hline & Association expert interaction \\
\hline
\end{tabular}

The method of calculating the generalized project management maturity. The general project management maturity degree calculation lies in the index weights of the indicators identified. Generally have three common methods- - AHP method, Delphi, and the combination of Delphi and AHP method. 
The AHP is a multi-objective and multi criteria decision-making method proposed by the American operations research expert and the professor Satty of University of Pittsburgh. It deals with people's subjective judgment in quantity. The main methods transform the index system into matrix, and determine the weight of the index [6]. The Delphi is mainly based on the concept and features of entropy in information theory to calculate the weights of the index. The specific operation construct the index matrix and some processing, calculate the entropy and entropy to determine the weight of the index [7].The combination of Delphi and AHP method is mainly according to their computational advantages of index weight, by introducing the concept of subjective and objective preference coefficient and by the method of linear weighted obtain the weight of index ${ }^{[8]}$.

\section{Summary}

In a word, through the research of the concept of generalized project management, the maturity level of generalized project management, and the evaluation system and calculation method of the maturity index of the project, this paper change the traditional project management and maturity into the generalized project management and maturity, which included the laboratory construction, quality management, academic exchanges, cultivation of experts, association participation .etc. For the large scale and intellectual type large enterprises is of great significance, can enhance the driving force for the development of enterprises, enrich the means of project management, improve enterprise in the market competition vitality, expand enterprise influence and the right to speak, and enhance the ability of enterprise to service innovation.

\section{References}

[1] Lu Qiaoyan.Strengthen Research Project Management. Chinese Hi-tech Enterprises.2013,6:113-115.

[2] Huang hui,Liang Gongqian,Xiao Mao. The Study on Foundation and Application of Enterprise Project Management Maturity Model. Journal of Industrial Engineering and Engineering Management.2005,19:67-72 .

[3] Huang Huiheng,Dong Xiongbao. The Application of PM3 in Manufacturing Enterprises. Value Engineering. 2010,20-0058-02:58-59.

[4] Zhan Wei,Qiu Kouhua. Theory and Application of Project Management Maturity Model. Journal of Beijing University of Aeronautics and Astronautics (Social Sciences Edition).2007,3(20):18-21.

[5] Gong Jun,Chen Lei. On building internal control evaluation system of an enterprise. Journal of Henan Business College.2010,4(23):66-70.

[6] Shen Xiaorong,Wang Jie. Application of AHP on Evaluation System of Government Administration about Civicism. Journal of Electronic Science and Technology University.2007,2 (36):154-157.

[7] Ruan Xuhua. The analysis of financial risk assessment of university based on the information entropy method. Friend of accounting.2011,9:102-103.

[8] Zhao Yan. Research on the maturity evaluation of project management for high speed railway construction enterprises. Beijing Jiaotong University degree thesis.2011. 